\title{
SOLID WASTE MANAGEMENT: A CASE STUDY OF PHUKET OLD TOWN NIGHT MARKET, THAILAND
}

\author{
SINEENART PUANGMANEE \& KANLAYARAT CHUAISINUAN \\ Faculty of Science and Technology, Phuket Rajabhat University, Thailand
}

\begin{abstract}
Phuket Old Town Night Market is a beautiful market in Thailand. The market is located among picturesque Sino-Portuguese houses in Phuket Old Town. The spaces between the buildings are packed with stalls selling traditional local foods and beverages, Thai handicrafts, modern fashions, and souvenirs. Solid waste is produced from the many activities within the market area. Therefore, this paper aimed to study solid waste management at the night market in Phuket Old Town and aimed to study the types and quantities of solid waste, waste storage, waste collection, transfer and transportation, and disposal of the waste products. The waste selected from 24 bins at 14 bin points in the market area produced four types of waste: organic waste $(52 \%)$; general waste $(40 \%)$; recyclable waste $(7 \%)$; and hazardous waste $(1 \%)$. The average generation rate of the waste was 0.03 $\mathrm{kg} /$ person/day. The waste materials from the bins were collected by six employees of the municipality who wore unsuitable protective suits while working. They collected waste materials from transparent plastic bins that were 50 and 70 litres in size and green plastic bins that were 240 litres in size. All bins were fitted with black or transparent plastic bags. All waste materials were carried and transferred for disposal by two municipal employees in a vehicle provided by the municipality. According to the government guidelines, the transport workers wore unsuitable clothing. Furthermore, the waste materials were transferred and transported without separation at the source. The waste was taken to an incineration plant for disposal. The municipality, president of Phuket Old Town, and the organizer should manage the solid waste materials more strictly according to the 3Rs to reduce the amount of waste for incineration. They also need to prepare PPE suits for the waste handlers. Also, volunteers should be available to advise visitors on waste segregation within the market.
\end{abstract}

Keywords: solid waste management, Phuket Old Town, night market.

\section{INTRODUCTION}

Phuket province in southern Thailand is a famous and popular destination for both Thai and foreign tourists. In 2020, the number of tourists who visited Phuket was 14,454,187 and the income from the tourism was 471,606 million Thai baht [1]. Phuket is the largest island in Thailand, and it has many beautiful natural resources such as Patong Beach, Promthep Cape, and Mai Khao Beach, which is near the airport. There are also traditional foods, sweets, beverages, clothing, and local traditional and historic architecture, especially the Sino-Portuguese architecture of the buildings in Phuket Old Town.

In Phuket Old Town, Thalang Road is lined with colourful 19th-century shophouses and Sino-Portuguese buildings, and it is the location of Phuket Old Town Night Market (POTNM). The market is open every Sunday afternoon until evening $(4.00 \mathrm{pm}-10.00 \mathrm{pm})$. Most visitors come into the market ahead of time for sightseeing of the old Sino-Portuguese buildings that line the 350-metre-long street [2]. Within the market, the visitors can take photos of street art graffiti and old colourful Portuguese houses. In addition, inside the market, various foods, beverages, goods, and souvenirs are sold, such as Thai traditional foods and sweets, fruit juices, ice cream, Thai handcrafts, and gifts [3]. In addition, visitors can participate in activities within the market and listen to musical performances. Phuket Old Town Night Market is therefore a kind of street night market that is popular and attracts groups of Thai and foreign tourists. However, the impact of the tourists produces an 
important environmental urban problem related to solid waste. Therefore, this research aimed to study solid waste management in Phuket Old Town Night Market. The information and collected data included the types and quantities of waste, waste storage and collection, waste transfer and transport, and waste disposal.

\section{METHODOLOGY}

\subsection{Area site}

The waste materials were produced in the Phuket Old Town Night Market in Phuket province in southern Thailand. This market is located among the picturesque SinoPortuguese houses in Phuket Old Town. The spaces between the buildings are packed with stalls selling traditional local food and beverages, Thai handicraft, modern fashions, and souvenirs (Fig. 1).

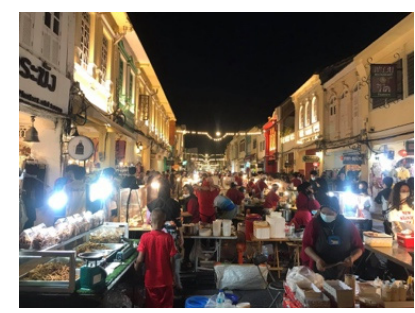

(a)

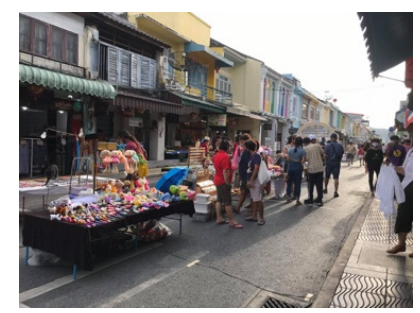

(b)

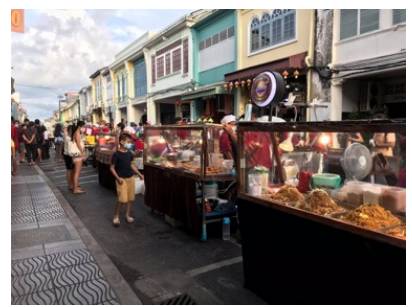

(c)

Figure 1: Phuket Old Town Night Market in Phuket, Thailand. (a) Market overview; (b) Goods and souvenir zone; and (c) Food and beverage zone.

\subsection{Survey methods and sampling}

Meetings were conducted with the president of Phuket Old Town, waste handlers and employees of Phuket City Municipality, and the organizer who managed and operated the market. The results of the meetings provided information for the methods of performing the research. The exploration included studies in the types and quantities of waste, waste storage and collection, waste transfer and transport, and waste disposal.

\subsection{Sampling scope}

The waste materials were identified according to the types and quantities by segregation and weighed on 29 December 2019 between $4.00 \mathrm{pm}$ and $10.00 \mathrm{pm}$ while the market was open on a Sunday afternoon. The waste was collected from 24 bins at 14 bin points within the market in two zones, which were the goods and souvenir (gs) zone and the food and beverage ( $\mathrm{fb}$ ) zone.

\section{RESULTS AND DISCUSSION}

\subsection{Types, components, and quantities of waste materials}

The total amount of waste materials in Phuket Old Town Night Market was $703.95 \mathrm{~kg}$ from the gs zone and $\mathrm{fb}$ zone and were separated into four types of waste, i.e., organic waste, 
general waste, recyclable waste, and hazardous/infectious waste. The average generation rate of the waste was $0.03 \mathrm{~kg} /$ person/day. The greatest percentage of waste was organic waste at $52 \%(365.32 \mathrm{~kg})$, and hazardous/infectious waste was the lowest percentage at $1 \%$ (7.62 kg) (Fig. 2). Although POTNM is different from fresh markets, street food markets, or traditional food markets, the amount of organic waste was similar to those sources of solid waste. The high quantity of organic waste was similar to a study by Aye and Widjaya [4] and Huang [5] that reported waste compositions from traditional food markets in Bandung, Jakarta, and street food markets in mainland China.

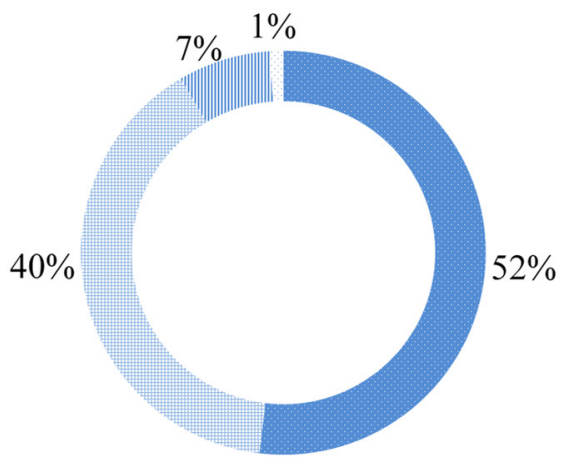

国 Organic waste $\quad$ General waste $\|$ Recyclable waste Hazardous/infectious waste

Figure 2: Percentages of waste materials in Phuket Old Town Night Market.

The amounts of waste in the gs zone and $\mathrm{fb}$ zone were $374.58 \mathrm{~kg}$ and $329.37 \mathrm{~kg}$, respectively. The types, components, and quantities of all waste materials are shown in Tables 1 and 2.

Table 1 shows the categories, components, and the amounts of waste from the gs zone. The highest amount was represented by organic waste at $213.98 \mathrm{~kg}$ that included coconuts and food waste. The second highest amount of waste was general waste at $123.75 \mathrm{~kg}$ that included cups, plates, glass, straws, paper, single use plastic, such as bags, boxes, cups, spoons, and straws, wooden skewers for ice cream and meat balls, chopsticks, shoe, and foam. Next, the amount of recyclable waste was $29.23 \mathrm{~kg}$ that included bottles (glass and plastic) and aluminium cans. Hazardous/infectious waste included expired cosmetic products, diaper, and sanitary napkin. The source of these waste products was found to be from people living in the nearby buildings who took them to the bin points within the market.

Table 2 shows the categories, components, and the amounts of waste from the $\mathrm{fb}$ zone. General waste represented the highest amount at $155.28 \mathrm{~kg}$ that included paper cups and plates, glass, and straws), paper, single use plastic, such as bags, boxes, cups, spoons, straws, wooden skewers for ice cream and meat balls, chopsticks, foil, foam and a telephone case. The second highest amount of waste was organic waste at $151.34 \mathrm{~kg}$ that included coconuts and food waste. The amount of recyclable waste was $22.75 \mathrm{~kg}$ that included bottles (glass and plastic) and aluminium cans. Hazardous/infectious waste products were not found in this area. Interestingly, the percentages of waste at the gs zone and fb zone were similar (Fig. 3). 
Table 1: Types, components, and quantities of waste in goods and souvenir zone.

\begin{tabular}{|c|c|c|}
\hline Types and components & Wet weight $(\mathrm{kg})$ & Percentage by weight \\
\hline \multicolumn{3}{|l|}{ 1. Organic waste } \\
\hline - Coconuts & 161.90 & 13.90 \\
\hline - Food waste & 52.08 & 43.22 \\
\hline Total & 213.98 & 57.13 \\
\hline \multicolumn{3}{|l|}{ 2. General waste } \\
\hline - Paper cups/plates/glass & 36.20 & 9.66 \\
\hline - Papers & 25.40 & 6.78 \\
\hline - Plastic bags & 18.01 & 4.81 \\
\hline - Plastic boxes & 15.14 & 4.04 \\
\hline - Plastic cups & 15.13 & 4.04 \\
\hline - Paper straws & 6.73 & 1.80 \\
\hline $\begin{array}{l}\text { - Wooden skewers for ice cream and } \\
\text { meatballs, chopsticks }\end{array}$ & 2.78 & 0.74 \\
\hline - Plastic spoons & 1.83 & 0.49 \\
\hline - Plastic straws & 1.79 & 0.48 \\
\hline - Shoe & 0.40 & 0.11 \\
\hline - Foam & 0.34 & 0.09 \\
\hline Total & 123.75 & 33.04 \\
\hline \multicolumn{3}{|l|}{ 3. Recyclable waste } \\
\hline - Glass bottles & 18.14 & 4.84 \\
\hline - Plastic bottles & 7.21 & 1.92 \\
\hline - Aluminium cans & 3.88 & 1.04 \\
\hline Total & 29.23 & 7.80 \\
\hline \multicolumn{3}{|l|}{ 4. Hazardous/infectious waste } \\
\hline - Expired cosmetic products & 6.80 & 1.82 \\
\hline - Diaper & 0.80 & 0.21 \\
\hline - Sanitary napkin & 0.02 & 0.01 \\
\hline Total & 7.62 & 2.03 \\
\hline Overall total & 374.58 & 100.00 \\
\hline
\end{tabular}

\subsection{Waste storage and collection}

The waste from 24 bins at 14 bin points in the two main zones in POTNM were not separated at the sources. All waste materials were mixed together inside the bins. However, the waste handlers were permitted by the municipality to segregate recyclable waste from the bins before moving the waste to a storage location. Most of the waste materials were collected and carried to the storage location by six waste handlers.

Before the market opened at $4.00 \mathrm{pm}$, the waste handlers put plastic bags inside 24 bins and carried them to the 14 bin points within the market (six bin points in the gs zone and eight bin points in fb zone). The types of bins consisted of (1) transparent plastic bins of two sizes (50 and 70 litres); and (2) green 240-litre plastic bins. All bins had transparent or black plastic bags. When the bins were full, the waste handlers collected the waste and moved it to the storage point. Next, they placed new plastic bags inside the bins at all bin 
Table 2: Types and components of solid waste in food and beverage zone.

\begin{tabular}{|c|c|c|}
\hline Types and components & Wet weight $(\mathrm{kg})$ & Percentage by weight \\
\hline \multicolumn{3}{|l|}{ 1. Organic waste } \\
\hline - Coconuts & 76.44 & 23.21 \\
\hline - Food waste & 74.90 & 22.74 \\
\hline Total & 151.34 & 45.95 \\
\hline \multicolumn{3}{|l|}{ 2. General waste } \\
\hline - Paper cups/plates/glass & 47.40 & 14.39 \\
\hline - Papers & 38.22 & 11.60 \\
\hline - Plastic bags & 18.25 & 5.54 \\
\hline - Plastic cups & 16.42 & 4.99 \\
\hline $\begin{array}{l}\text { - Wooden skewers for ice cream } \\
\text { and meatballs, chopstick }\end{array}$ & 10.85 & 3.29 \\
\hline - Plastic boxes & 10.53 & 3.20 \\
\hline - Paper straws & 6.14 & 1.86 \\
\hline - Plastic spoons & 4.82 & 1.46 \\
\hline - Plastic straws & 2.42 & 0.73 \\
\hline - Foil & 0.20 & 0.06 \\
\hline - Foam & 0.02 & 0.01 \\
\hline - Telephone case & 0.01 & 0.01 \\
\hline Total & 155.28 & 47.14 \\
\hline \multicolumn{3}{|l|}{ 3. Recyclable waste } \\
\hline - Glass bottles & 12.40 & 3.76 \\
\hline - Plastic bottles & 8.87 & 2.69 \\
\hline - Aluminium cans & 1.48 & 0.45 \\
\hline Total & 22.75 & 6.91 \\
\hline 4. Hazardous/infectious waste & Not detected & - \\
\hline Overall total & 329.27 & 100.00 \\
\hline
\end{tabular}

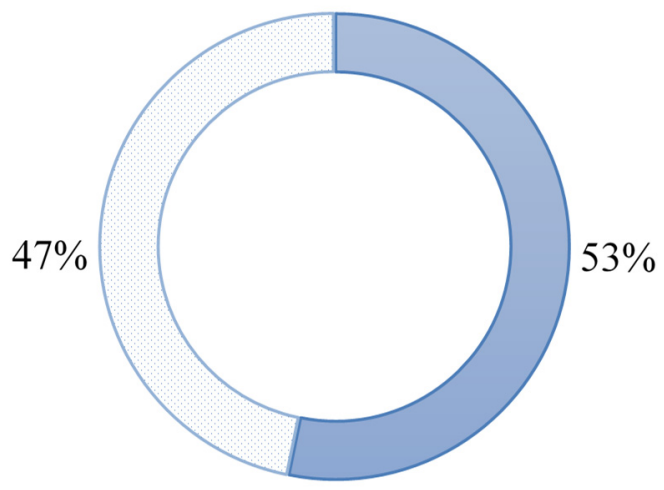

\section{goods and souvenir zone $\square$ food and beverage zone}

Figure 3: Percentages of waste at the goods and souvenir zone and food and beverage zone. 
points. They were repeated this procedure until the market was closed. At the storage point, a 1.44 tonne compactor garbage truck provided by the municipality waited outside the market to receive the waste. The waste handlers wore unsuitable protective clothing while working. They did not wear breathing masks, gloves, rubber boots, medical caps, or eye goggles. They wore only a short apron that did not conform to the guidelines by the Ministry Regulation on General Waste management B.E. 2560 (2017) [6].

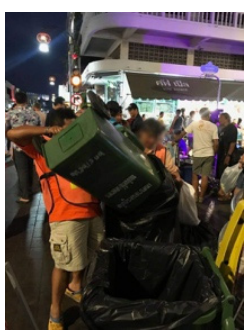

(a)

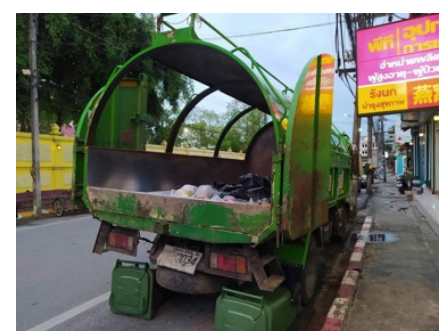

(b)

Figure 4: Waste storage and collection. (a) Waste collection by waste handler; and (b) Waste storage by compactor garbage truck.

\subsection{Waste transfer and transportation}

All waste from the 24 bins at the 14 bin points were transferred to the storage point by six waste handlers using carts. The waste materials were then transported from the storage point by a compactor garbage truck for disposal. The vehicle for waste transfer and transport was suitable and correct according to the laws of Thailand [6]. This waste was moved for disposal by incineration by two waste handlers in two round trips. The first trip was at around $9.00 \mathrm{pm}$. The final trip was conducted after the six waste handlers had completely cleared and cleaned any residue waste within the market.

The waste handlers wore unsuitable protective clothing during waste transfer and transportation. They did not wear breathing masks, gloves, rubber boots, medical caps, or eye goggles. They wore only a short apron that did not conform to the guidelines set by the Ministry Regulation on General Waste management B.E. 2560 (2017) [6].

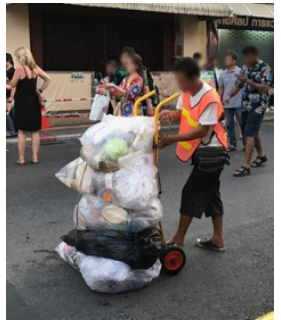

(a)

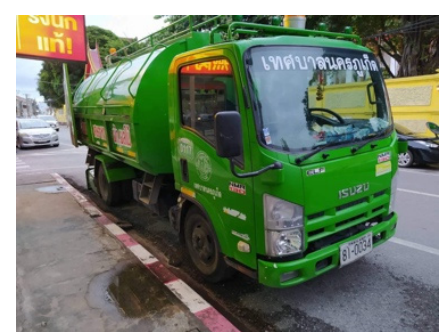

(b)

Figure 5: Waste transfer and transportation. (a) Waste transfer by cart; and (b) Waste transportation by compactor garbage truck. 


\subsection{Waste disposal}

Most waste materials from the market were mixed together and moved for disposal by incineration. However, some of the recyclable waste was separated out by the waste handlers who were permitted by the municipality to segregate the waste before moving it to the storage point. The recyclable waste was taken to recycling shops for disposal. The handling of recyclable waste was carried out correctly according to the requirements [6]. On the other hand, the hazardous/infectious waste materials were not separated according to the type of bin and disposal method. The waste contaminated with pathogens from diapers and sanitary napkins and toxic substances from expired cosmetic products should not be incinerated with the general waste. Furthermore, it was not possible to burn some of the waste. A flow chart of solid waste management at the POTNM is shown in Fig. 6. Most of the waste materials were not separated at the source. Unfortunately, some waste was contaminated with toxic substances and pathogens from hazardous/infectious waste. The waste products were put into a total of 24 bins by visitors who came to the market. Six waste handlers collected and transferred the waste to a storage location. The waste handlers segregated some of the recyclable glass and plastic bottles by removing them from the bins. The waste materials were then taken to the storage point where a compactor garbage truck was parked outside the market. When the market closed at $9.00 \mathrm{pm}$, two waste handlers transported the waste to an incinerator plant for disposal using a compactor garbage truck. It was observed that all eight waste handlers wore unsuitable protective equipment. Solid waste management at the POTNM can be compared to a study by Huang [5] that reported on the solid waste disposal process in street markets in mainland China. That process could be classified into three stages: (1) storage: setting containers in designated locations for scheduled pickups; (2) collection and transportation: solid waste was carried out using various types of vehicles that depended on the type of collection bin and width of the road; and (3) final disposal: three important waste disposal methods were incineration, biochemical treatment, and landfill.

\section{CONCLUSION AND RECOMMENDATIONS}

The waste at the POTNM was classified into four categories from 24 bins at 14 points in two main zones. The types of waste in the gs zone consisted of organic waste, general waste, recyclable waste, and hazardous/infectious waste. The $\mathrm{fb}$ zone included organic waste, general waste, and recyclable waste. The percentage values of the waste materials at the gs and $\mathrm{fb}$ zones were similar. None of the waste handlers wore suitable protective clothing according to the laws of Thailand. However, the compactor garbage truck and disposal methods, ie incineration and recycling shop, were correct according to the Thai government guidelines. In Phuket, the final disposal methods of solid waste are mainly incineration and sanitary landfill for non-combustible waste.

However, the best practices for solid waste management in this case are to reduce and separate waste at the source, especially organic waste. Visitors should buy only sufficient food, fruits, sweets and beverages to be consumed without waste. The high water content of organic waste in a highly humid environment adds wet weight to the waste and becomes more difficult to incinerate. Therefore, organic waste needs to be separated from general waste to avoid adding wet weight that makes incineration less efficient. Since waste materials are usually stored at the incinerator plant for a long time before incineration, reducing the amount of organic waste going to the incinerator plant also makes the overall solid waste management more efficient. 


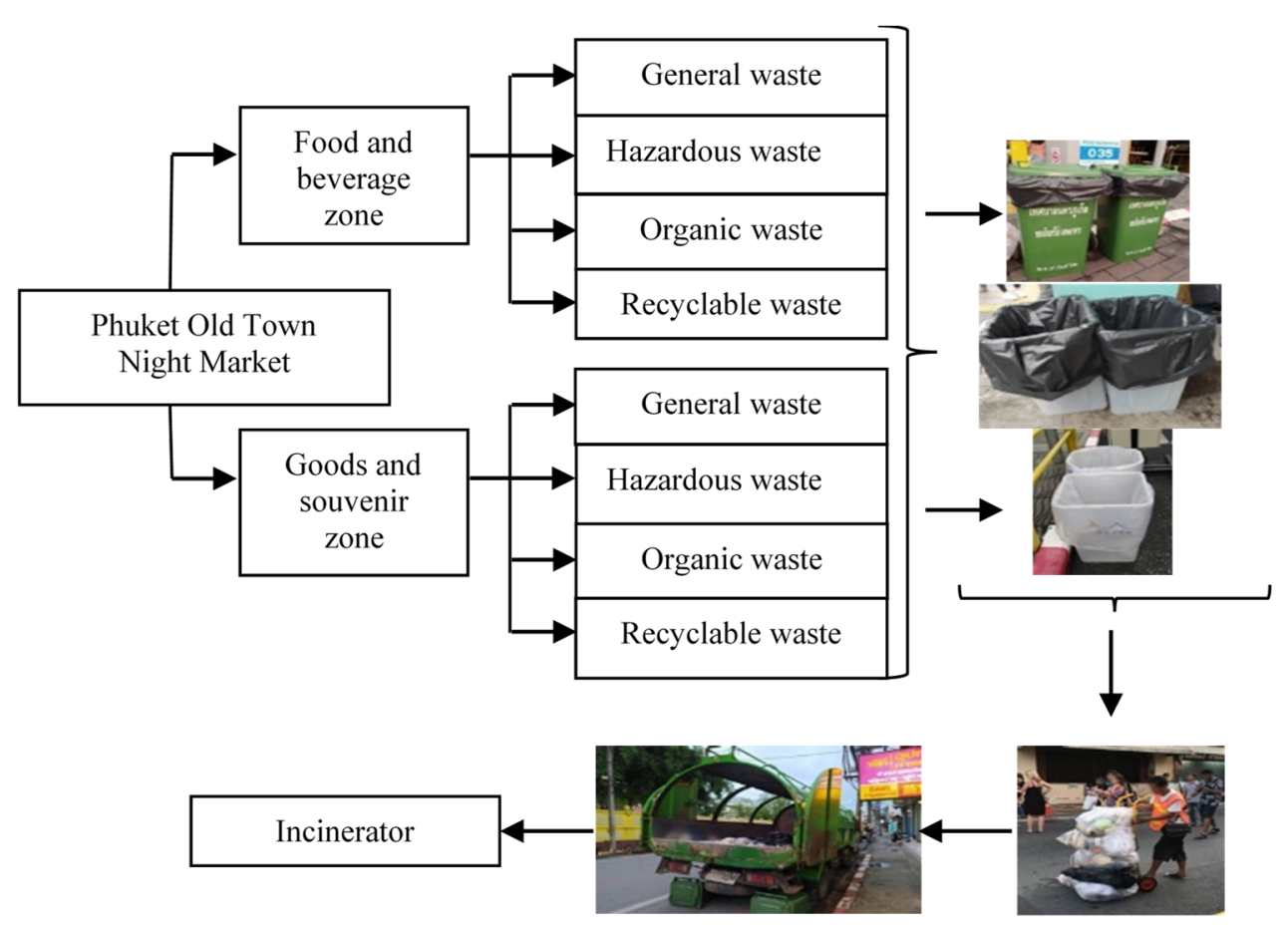

Figure 6: Flow chart of solid waste in Phuket Old Town Night Market.

The following are the recommendations for solid waste management at the POTNM: (1) The municipality, president of Phuket Old Town, and the organizer should plan to more strictly control and manage solid waste according to the 3Rs, ie Reduce, Reuse, and Recycle to reduce the quantity of waste for disposal by incineration and select proper methods for disposal of each type of waste. Bins need to be clearly labelled as organic waste, general waste, and recyclable waste for proper segregation. Special containers or bins inside the market are needed for hazardous/infectious waste for easier transfer to a special incinerator facility that is located near the general waste incineration facility; (2) Public announcements on solid waste management are needed within the market in at least three languages, such as Thai, English, Chinese, and Korean, for travellers and traders; (3) A team of volunteers should be available to advise visitors on waste segregation and control and management of the waste within the market; and (4) Suitable personal protective equipment and clothing need to be provided for the waste handlers.

\section{ACKNOWLEDGEMENTS}

The authors would like to thank Phuket Rajabhat University for financial support (PKRU Fund), Phuket City Municipality for their area site support, the president of Phuket Old Town, and the Art Factory Company (organizer) for information, data, and area site support.

\section{REFERENCES}

[1] Phuket Provincial Statistic Office. Phuket Provincial Statistic Report 2020. http://phuket.nso.go.th/. Accessed on: 3 Apr. 2021. 
[2] 5 great night markets in Phuket - Phuket's most popular night market. 3 Phuket Walking Street. https://th.hotels.com/go/thailand/great-phuket-night-markets. Accessed on: 14 Apr. 2021.

[3] Phuket walking street Sunday night market in Phuket old town. https://th.hotels.com/go/thailand/phuket-walking-street. Accessed on: 14 Apr. 2021.

[4] Aye, L. \& Widjaya, E.R., Environmental and economic analyses of waste disposal options for traditional market in Indonesia. Waste Management, 26, pp. 1180-1191, 2006.

[5] Huang, J., Design for street markets in Mainland China: Study of current street markets, the ideal model of formalized street markets, and worktable design. https://scholarworks.rit.edu/cgi/viewcontent.cgi?article=1135\&context=theses.

[6] Ministerial Regulation General Waste Management B.E. 2560. http://laws.anamai.moph.go.th/ewtadmin/ewt/laws/main.php?filename=2RLaws. Accessed on: 10 May 2021. 